\title{
The Political Economy of Skill Formation in a Rentier State: The Case of Oman
}

\author{
Margarita Langthaler ${ }^{\star 1}$, Stefan Wolf ${ }^{2}$, Tobias Schnitzler ${ }^{3}$ \\ ${ }^{1}$ Austrian Foundation for Development Research (Österreichische Forschungsstiftung für \\ Internationale Entwicklung - ÖFSE) Sensengasse 3, 1090 Vienna, Austria \\ ${ }^{2}$ Technical University of Berlin, Institute of Educational Science, Department of School and \\ Vocational Pedagogy, Sekr. FH 5-1, Fraunhoferstraße 33-36, 10587 Berlin, Germany \\ ${ }^{3}$ World University Service (WUS) Austria, Schmiedgasse 40/3, 8010 Graz, Austria
}

Received: 29 June 2021, Accepted: 21 January 2022

\begin{abstract}
Context: Against a backdrop of dwindling oil resources and increasing unemployment rates, the government of Oman has set out to diversify its industry and establish a knowledgebased economy. In this context, forming a highly-skilled Omani workforce is considered to be of crucial importance. Yet, the national TVET system suffers from low social status, poor quality, and limited labour market connectivity. This paper offers an analysis of Oman's TVET system in the socio-economic and cultural context of a rentier state.

Approach: We draw on the political economy of skills and socio-cultural approaches that understand TVET systems and the broader skills regimes in which they are embedded as part and expression of particular patterns of the social organisation of work. This helps to locate TVET systems' strengths and weaknesses in the context of their underlying social relations instead of considering them as mere dysfunctionalities at the systemic level. This paper draws on an unpublished study on TVET for industrialisation commissioned by an Omani line ministry in cooperation with an international organisation. For this study, the authors carried out a literature review, undertook two field trips to Oman in 2018 and 2019 and conducted forty semi-structured interviews with stakeholders from government, private companies, business associations, and TVET and higher education institutions.
\end{abstract}

*Corresponding author: m.langthaler@oefse.at 
Findings: Our analysis highlights how skill formation in Oman is shaped by the socioeconomic and cultural context of the Omani rentier state. First, the availability of cheap expatriate labour and Omanis' traditional preference for public sector jobs culminate in poor incentives for employing Omani nationals in the private sector. Second, reluctant employer attitudes towards national skill formation deepen quality issues in the TVET system, especially with regard to work-based training. This reinforces negative perceptions of the local workforce, which in turn contribute to biased employment patterns. Both social processes mutually reinforce each other, eventually preventing the emergence of strong national skill formation dynamics.

Conclusions: While immediate structural change appears challenging, it is evident that reforms of the TVET system alone will not lead to its sustainable improvement. More research into how skill formation relates to Oman's specific socio-economic structures, how employment dynamics relate to educational credentials and how cultural traditions shape educational and work practices is needed.

Keywords: Skill Formation, Rentier State, Oman, Vocational Education and Training, VET

\section{Introduction}

Global transformation processes of economies and labour markets put pressure on governments worldwide. Challenges include the availability of an adequately trained workforce to keep pace with transformations. In this context, Technical and Vocational Education and Training (TVET) has received increased attention globally. However, despite repeated reform efforts, TVET systems in many countries tend to suffer from poor social status and struggle to meet labour market demands (see, e.g., Allais, 2020b on Sub-Saharan Africa; UNICEF \& ILO, 2016 on the MENA Region).

Most research focuses on dysfunctionalities at the systemic level of TVET. Such approaches, however, do not suffice to explain the persistent failure of many TVET systems in assuming a supportive role in economic development strategies. In this paper, we draw upon political economy of skills and socio-cultural approaches that understand TVET systems and the wider skills regimes they are embedded in as part and expression of particular patterns of social organisation of work. These patterns are specific to each socio-economic context and essentially shaped by the competing interests of a variety of actors. Such an understanding of skills regimes helps to locate their strengths and weaknesses in the context of their underlying social relations instead of considering them as mere dysfunctionalities. We will apply these approaches to an analysis of the TVET system in Oman in the context of the government's industrialisation strategy. 
After fifty years of rapid development based on petroleum export and massive deployment of low-paid foreign labour, the country is facing severe challenges. Against the background of dwindling oil resources, demographic pressure and increasing unemployment rates among Omani nationals, the government has elaborated the development strategy "Vision 2040" (Oman Vision 2040, n.d.), which endeavours to achieve industrial diversification and the establishment of a knowledge-based and technology-driven economy. In this context, forming a highly-skilled Omani workforce is considered to be of crucial importance. However, while government commitment to TVET reform is high, the TVET system continues to suffer from low social status, poor quality, and lack of labour market connectivity.

TVET in Oman is a generally under-researched topic. Most literature is descriptive and policy-oriented, and while shortcomings are mentioned, they are rarely viewed in their socio-economic context. In this research, we argue that persistent challenges in skill formation have a great deal to do with the socio-economic setting of a rentier state ${ }^{1}$ in which the Omani skill regime is embedded. Based on this hypothesis, our research question deals with how the specific economic and labour market context of the Omani rentier state and its interrelation with the TVET system and policy level shape national skill dynamics.

In this paper, we first situate our work in a conceptual framework followed by a description of the socio-economic background of Oman and its education and TVET system. We then outline and discuss our findings, drawing upon the conceptual framework, before presenting our final remarks and conclusions.

\section{Conceptual Framework}

This paper is built upon two theoretical approaches. First, we follow a political economy of skills approach (Allais, 2020b; Brown et al., 2011; Busemeyer \& Trampusch, 2012b) in conceiving national skills systems as socially constructed and fundamentally political (Busemeyer \& Trampusch, 2012a). Second, we draw on a cultural and social science approach to TVET (Greinert, 2005, 2017; Wolf, 2017) to emphasise social and cultural practices and their impact on forming skills systems.

In contrast to much of the economic and policy literature, the political economy approach views skill formation systems as deeply embedded in their respective countries' socioeconomic patterns and framed by the political and social, often conflictive, relations between the actors involved (Streeck, 2012). Formal TVET systems are intertwined with the specific economic and, in particular, industrial development trajectories of their countries.

\footnotetext{
Following Beblawi (1987, pp. 384-386), we understand a rentier state as corresponding to a set of particular socio-economic features. These include economic structures where rent situations predominate and which rely on substantial external rent. In a rentier state, only few are engaged in the generation of the rent, while the majority is involved only in its distribution or utilisation. A fourth feature is that the government is the principal recipient of the external rent. Finally, it is assumed that such an economy creates a rentier mentality, associating reward to chance or situation, rather than to work and risk-taking.
} 
In trying to understand and compare the driving forces behind different skills formation systems, various typologies have been elaborated. Busemeyer and Trampusch (2012a), for example, use the two criteria of public commitment to education and training, as well as company involvement in initial education and training respectively, to identify four idealtype models of skill formation systems (see Table 1):

Table 1: Types of Skill Formation Systems

\begin{tabular}{l|l|l|l}
\hline $\begin{array}{l}\text { Public commitment to } \\
\text { vocational training }\end{array}$ & High & $\begin{array}{l}\text { Statist skill formation system } \\
\text { e.g. France }\end{array}$ & $\begin{array}{l}\text { Collective skill formation system } \\
\text { e.g. Germany }\end{array}$ \\
\cline { 3 - 4 } & Low & $\begin{array}{l}\text { Liberal skill formation system } \\
\text { e.g. USA }\end{array}$ & $\begin{array}{l}\text { Segmentalist skill formation } \\
\text { system } \\
\text { e.g. Japan }\end{array}$ \\
\hline \multirow{2}{*}{} & Low & High \\
\cline { 2 - 4 } & Involvement of firms in initial vocational training \\
\cline { 2 - 4 } &
\end{tabular}

Source: Busemeyer \& Trampusch (2012a, p. 12)

In liberal skill regimes, such as in the USA or the United Kingdom, the markets and the general education system primarily provide for skill formation, complemented with narrow on-the-job training. While institutional settings in segmentalist skill formation systems, e.g. Japan, are similar to those in the liberal type, firms are much more willing to invest in intensive skills training of newly-hired school graduates. Statist skill formation models, e.g. French or Swedish TVET systems, are mostly state-run and school-based, and TVET enjoys high levels of support from policymakers. In collective skill regimes, e.g. across the Germanspeaking world, skills formation is collectively governed by firms, associations and the state, and both government and private sector commit to investing in TVET (Busemeyer \& Trampusch, 2012a; on the German-speaking countries see also Bürgi \& Gonon, 2021).

Besides these ideal-type models, many national TVET systems could be classified as hybrid models (see, for instance, Souto-Otero \& Ure (2012) on TVET models in Spain and Norway). In recent years, discussion on hybridisation has highlighted different forms of organisational and institutional responses to the gap between TVET and higher education. In essence, hybrid forms provide double qualifications allowing for both immediate entry into the labour market and access to higher education. Increasingly, discussions focus upon whether such hybridisation trends call the classic typologies of governance into question (e.g., Deissinger et al., 2013; Graf, 2013, 2016).

We complement the political economy typology by Busemeyer and Trampusch (2012a) with another typology that opens up the picture to cultural patterns, common understandings, traditions and practices of skill formation. Wolf (2017), drawing on a social and 
cultural sciences approach and elaborating upon the classic typology by Greinert (2005, 2017), uses patterns of social regulation and governance to distinguish between the traditionbased, market-based and bureaucracy-based types of TVET systems (see Figure 1).

\begin{tabular}{|l|l|l|}
\hline $\begin{array}{c}\text { Regulatory and governance } \\
\text { patterns }\end{array}$ & $\begin{array}{c}\text { Factors shaping TVET } \\
\text { Tradition }\end{array}$ & $\begin{array}{l}\text { Traditional action, legitimised } \\
\text { by customary law }\end{array}$ \\
\hline Market & $\begin{array}{l}\text { Production factor labour and } \\
\text { the qualification requirements } \\
\text { of the labour market }\end{array}$ \\
\hline Bureaucracy & $\begin{array}{l}\text { Legal regulations of state } \\
\text { agencies and state bureaucracy }\end{array}$ \\
\hline
\end{tabular}

Figure 1: Ideal Types of TVET Regulatory and Governance Patterns

Source: Own compilation, based on Wolf (2017)

Speaking of governance and regulation, Greinert questions what it is that makes communication partners in the social action system of vocational education follow regulations and accept similar patterns of interpretation of their actions (Greinert, 1995, p. 31, translation by the authors). He points to particular regulatory patterns which, providing a meaningful basis for understanding and establishing the legitimacy of social actions, facilitate coordination of complex interactions in a social sub-sector such as TVET. Through these regulatory patterns, members of a society can easily agree on what is meant by good vocational education and training, creating a "common sense" on TVET models deriving from historical processes (Wolf, 2021b, pp. 217). Regulatory patterns can be assigned to specific legitimation principles derived from the history of European ideas, whereby social action and social stability follow the principles of "Tradition (or the professional (Beruf) principle) - Liberalism (or the market principle) - Rationalism (or the scientific principle)" (Greinert, 2005, p. 15, translation by the authors).

In his historical comparison of European TVET models, Greinert (1995) distinguishes between three ideal types of regulatory patterns. Firstly, a tradition-based pattern is associated chiefly with corporatist TVET models, generally based on (economic) communities (e.g. in Germany). Yet, it can also apply to cross-community associations based on informal settings (e.g. the construction sector in Egypt). 
Secondly, a market-based pattern is associated with a market-driven TVET model (e.g. in Anglo-Saxon countries), which is determined by rules of supply and demand, i.e. qualified employees offer themselves to paying employers through the labour market. Thirdly, association with a state-organised, school-based TVET model (e.g. in France and francophone Africa) points to a pattern of bureaucracy (Wolf, 2021a).

Following their specific regulatory patterns, each type of TVET system embodies different manifestations of social activities and has different training outcomes (see Figure 2).

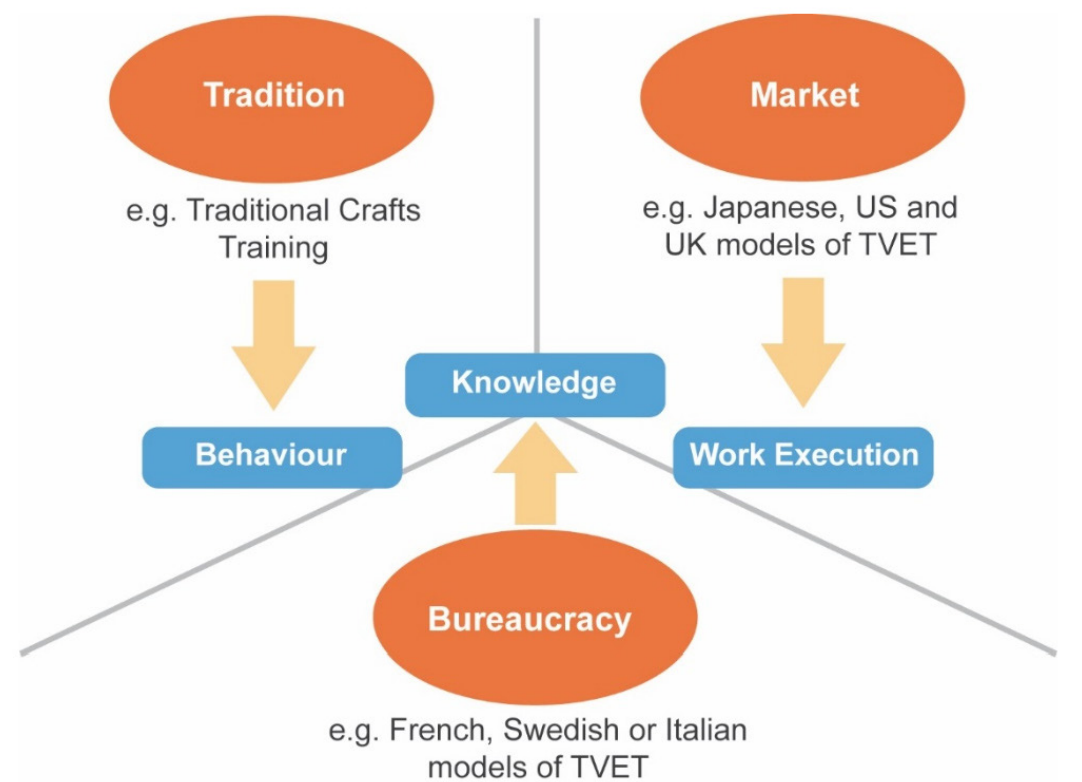

Figure 2: TVET Systems and Manifestations of Social Activities

Source: Own compilation, based on Wolf (2017)

While in practice, many TVET systems might have hybrid regulatory modes these comparative typologies are helpful when analysing national skill regimes as part of their socioeconomic and cultural contexts.

However, it has to be noted that most literature on the political economy of skills focuses on Western economies, largely neglecting other parts of the world. Al-Shabibi (2020), in his study on entrepreneurship promotion in Oman, complements Busemeyer's and Trampusch's (2012a) model with categories from the discussion on development and rentier state economies. He emphasises how East-Asian development states such as Singapore had strong government-led macroeconomic policies, including on skill formation, which helped them make the leap from underdeveloped to newly industrialised or even knowledge-based economies. 
Ashton et al. (2002) describe the skill formation models of Singapore, South Korea and Taiwan as contingent responses to particular internal and external conditions. ${ }^{2}$ An important factor for the emergence of what they call the "developmental model of skill formation" (Ashton et al., 2002, p. 11) included external threats and the ensuing internal pressure by elites to preserve independence through rapid economic development. They see this model widely based on the three components of centralised control over the education system, a clear trade and industry policy and innovative mechanisms to ensure that the industrial skills requirements were guiding education and TVET policies. In Singapore, such policies materialised upon the Ministry of Trade and Industry being granted decision-making powers that superseded all other governmental agencies. Close control over access to higher education served as the basis to channel parents' demands for social mobility to TVET rather than university education. Finally, a strategic alliance with multinational companies and, of lesser importance, with consensual trade unions ensured close cooperation between industries and TVET institutions.

While strong state interventionism is also found in rentier states such as Oman, decisive differences lie in the centrality of skill formation in government policies, the strength of the private sector and the skills demands that this entails. Al-Shabibi (2020) emphasises that Oman's rentier economy has led to a structurally small private sector, particularly in manufacturing, with weak traditions of industrial skills training. It is obvious, therefore, that the typology by Busemeyer and Trampusch (2012a), while useful in guiding analyses of socioeconomic backgrounds to TVET systems, will not suffice to explain their particularities in rentier states such as Oman. Complementing this concept with socio-cultural approaches, which are particularly helpful to better understand non-Western skill formation systems ${ }^{3}$, we can identify the origins of modes of governance, rules and regulations, and understand specific outcomes, strengths, and weaknesses as rooted in the underlying socio-cultural relations rather than as dysfunctionalities of the TVET system. For the purposes of this study, the combination of both approaches helps to situate the analysis of the Omani skill formation system in its broader context of a rentier society with "rentier mentality" (Beblawi, 1987, p. 385).

\footnotetext{
2 Similarly, Allais (2020a, 2020b) points to the (missing) link between TVET and economic development in Sub-Saharan Africa. She describes how, as an effect of colonialism, education and, even more so, TVET systems have never emerged out of the economic realities of African countries, mostly characterised by agrarian subsistence and informal economies. Repeated reforms have tended to tackle TVET provision rather than the missing interlinkages with the economic context. Hence, while TVET systems indeed suffer from poor quality, missing labour market opportunities for TVET graduates and a distorted system of school credentials inherited from colonial education turn out to be major structural inhibiting factors to the systems' improvement.

3 Wolf has worked extensively on socio-cultural approaches to TVET in Non-Western countries, pointing out that often tradition-based skill transmission co-exists with formal TVET systems (Wolf, 2018, see also Wolf, 2021a and b).
} 


\section{Methodology}

This paper draws on an unpublished study on TVET for industrialisation commissioned by an Omani line ministry in cooperation with an international organisation. For this study, we carried out an extensive literature review covering academic literature, policy papers and grey literature. We undertook two field trips to Oman in 2018 and 2019, where we conducted forty semi-structured interviews following Bogner et al.'s (2009) conception of expert interviews. Our interview partners included stakeholders from the ministries of manpower, education, higher education as well as commerce and industry, government agencies (e.g. the Education Council, the Occupational Standard Centre), state and private companies, business associations, and TVET and higher education institutions.

Due to local regulations, the interviews could not be recorded, but detailed interview reports were written. Following a triangulation approach, we compared distinct data sources (literature, interview reports, government statistics) in an effort to complement and validate sources (Hammersley, 2008). In terms of complementary data, the interviews were particularly informative on issues of work-based learning, company involvement in skill formation and socio-cultural practices in workplaces. We assessed the distinct data sources using content analysis by Mayring (2010) and contrasted the generated categories. Finally, we condensed them into our findings.

\section{The Socio-Economic Context of Skill Formation in Oman}

In 1970, Sultan Qaboos Ibn Said seized power by overthrowing his father, Sultan Said Bin Taimur, with the help of the British. Previously, the country had been under extremely isolationist and conservative rule with widespread poverty and illiteracy. A popular left-wing uprising in the Southern province of Dhofar had claimed independence and major social reform. Once in power, Sultan Qaboos crushed this uprising and introduced broad economic, political and social reforms that boosted a rapid development process (Peterson, 1978; Valeri, 2013). The discovery of petroleum in the 1960s and the commencement of oil exploration, as in its neighbouring Gulf countries, soon came to be the foundation of Oman's "Renaissance"; the rapid socio-economic development process initiated by Sultan Qaboos.

Following the Dhofar uprising and earlier internal warfare ${ }^{4}$, modern Oman's political system is based on well-orchestrated internal power balances, which confer a high degree of political stability to the absolute monarchy (Valeri, 2013). Distributive, albeit stratifying, social policies compensate for restricted democratic participation (Ennis, 2015). However, a range of economic, social and political challenges is putting this model at risk. Dwindling oil resources and a growing youth bulge are increasingly limiting the effects of distributive

\footnotetext{
4 On the so-called Jebel Akhdar War and the Dhofar uprising see Petersen (1978).
} 
policies. In early 2011, and against the background of the broader Arab spring movements, Omani youth took to the streets to demand democratisation, employment, and education opportunities (Al-Shabibi, 2020; Ennis, 2015; Worrall, 2012).

To cope with these challenges, the government has elaborated its development strategy, "Vision 2040" (Oman Vision 2040, n.d.), to boost employment and reduce the country's dependence on oil resources. The strategy aims to diversify the economy and upgrade it from resource-based to knowledge-based and technology-driven patterns. Education and TVET are seen as crucial tools to supply the economy with a highly-skilled workforce and resolve the issue of unemployment. However, the TVET system continues to be weak.

The socio-economic settings described above decisively shape the national skill formation dynamics. Four contextual factors stand out. First, the petroleum-related state-run industry is by far the most important economic sector. Second, a high share of immigrant labour has resulted in a dual labour market with different wage structures, regulations and legal protection. Third, Omanis traditionally prefer to seek work in the public rather than the private sector. Fourth, this is despite relatively high unemployment rates, especially among young Omanis (Ali et al., 2017; Al-Shabibi, 2020; Ennis, 2015, 2020).

The total population of Oman rose from 2.7 million in 2010 to 4.6 million in 2019, with immigrants amounting to almost 2 million in 2019. The number of immigrant workers has been increasing steadily over recent decades, widely outnumbering Omanis, especially in the private sector (see Figure 3).

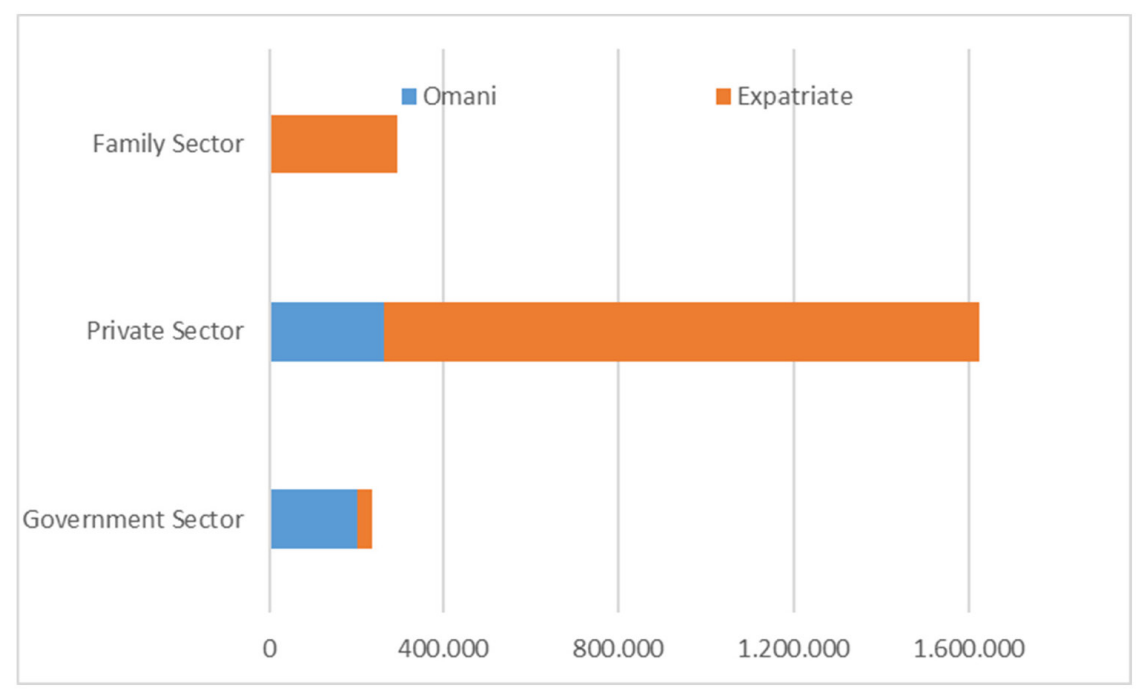

Figure 3: Employment per Sector and Nationality in 2019 (total number) 
The number of immigrant workers has almost doubled since 2010, accounting for 1,692,581 in 2019. Between 2010 and 2019, immigrants' share in the private sector slightly rose from $82.91 \%$ to $83.87 \%$ (NCSI, 2020, pp. 107).

Notably, by far the biggest group of workers in terms of skills levels are those of "limited skills" (51.68 \% of the total workforce in 2019). Among these, $91.65 \%$ are immigrants (NCSI, 2020 , p. 121). This suggests that the private sector continues to employ a readily available, low-skilled and low-wage immigrant workforce rather than embarking on technological upgrading and upskilling. At the same time, youth unemployment among Omanis is relatively high. In $2019,8.5 \%$ of the 18 to 24 -year olds and $6 \%$ of the 25 to 29 -year olds were unemployed. Rates among females are significantly higher, at $16.5 \%$ and $25.2 \%$, respectively (NCSI, 2020, p. 133). In 2020, the combination of the Covid 19 pandemic and the drop in oil prices led to a further tightening of the job market (Ennis, 2020).

While the informal sector is very small (Ohnsorge \& Yu, 2021), small and medium enterprises (SMEs) account for the vast majority of registered companies and employ $40 \%$ of the workforce (Riyada, 2018). The government considers SME development as a priority in striving for economic diversification and has founded the agency Riyada for these purposes. Skills levels are reported to be low across the SME sector and, since a considerable share of SMEs includes micro and small enterprises, most do not have membership in business associations and experience considerable difficulties in addressing their training needs.

In the 1990s, the government introduced the so-called Omanisation strategy, requiring employers to hire a certain percentage of Omani nationals, e.g., 35\% in the manufacturing sector (Al-Lamki, 2000). In the aftermath of the financial crisis, Omanisation has been reinforced to counter rising unemployment rates. However, while the strategy has been successful in specific sectors, such as banking, results in others, including industry and construction, are weak (see also Al-Shabibi, 2020).

\section{The Education and TVET System}

Oman's education system has experienced impressive expansion since its introduction in 1970. Prior to this, there were only three boys' schools in the entire country (Al Najar, 2016). Today, more than 2,000 schools account for a student population of 843,598 (NCSI, 2020, p. 402). In 2019, the net enrolment ratio in secondary education stood at $96.4 \%^{5}$. However, while participation is high, quality is still an issue. Despite major evaluation studies (World Bank \& Oman Ministry of Education, 2012) and subsequent reform efforts, particularly in teacher education, performance of the school system is still perceived to be weak. This is reflected in the mandatory foundation year, which students must undergo before embarking on any post-secondary educational pathway (Al-Shabibi, 2020; Nasser, 2020). Higher education

\footnotetext{
5 Unesco Institute for Statistics: http://uis.unesco.org/en/country/om (21/11/2021)
} 
has similarly expanded since being introduced in the 1980s with a focus on technical training. Sultan Qaboos University (SQU), the only public university, was established in 1986.

Public education, including schools and institutions of higher education, is largely restricted to Omani citizens, for whom this is free of charge. In the 1990s, in light of increasing demand, the government decided to allow for the establishment of private universities and colleges, contributing substantially to the expansion of higher education (Brandenburg, 2013). The gross enrolment ratio in tertiary education rose from $27 \%$ in 2011 to $40.4 \%$ in 2019 , those of female students from $33.1 \%$ to $55.3 \% .{ }^{6}$ In $2018 / 19$, out of a total of 119,184 students at tertiary level, 55,474 were registered at private institutions (NCSI, 2020, p. 415). However, the quality of higher education, particularly in private institutions, may be inconsistent (AlShabibi, 2020). Brandenburg (2013) describes how the privatisation of higher education has led to segmentation of the sector. While the public SQU addresses the domestic elite, the many private for-profit institutions absorb the mass of secondary school graduates. Unlike graduates from the SQU, those from private institutions do not easily find employment in the public sector.

In 1967, the modern TVET system was introduced in the context of the emerging petroleum industry (Al-Rawahi, 2011). Later, the government established vocational training centres at secondary and technical industrial colleges at post-secondary level (Al-Raisi, 2000). In 1991, the High Committee for Vocational Training was set up, whose primary purpose soon became to promote the Omanisation of the workforce. Since then, TVET policy has been shaped by the overarching Omanisation imperative (Al-Lamki, 2000). New TVET regulations introduced in 2015 differentiate between four sub-sectors under the responsibility of the Ministry of Manpower (MoM): Technological education at post-secondary level in colleges of technology; vocational education and training at secondary and post-secondary level in governmental vocational training centres; fisheries institutes and private training institutes (Al-Mujaini, 2018). The Ministry of Higher Education (MoHE) recently introduced Colleges of Applied Sciences (Al Shabibi, 2020). A range of further specialised training institutions also fall under the remit of different line ministries and, in further efforts to strengthen vocational training, the government upgraded the Vocational Training Centres into Vocational Colleges and introduced a new national training system comprising three pathways: Postsecondary diploma courses, apprenticeships schemes and short-term training courses ${ }^{7}$. In recent years, a significant number of private training institutes have also emerged; however, while accredited and supervised by the MoM, the private training market appears to be only minimally regulated (Jax, 2012) with diverse quality standards (Klaffke, 2010).

In terms of enrolment numbers, only a small percentage of youth are trained in the public vocational training system. In 2019, 5,394 persons were registered in vocational colleges

6 Unesco Institute for Statistics: http://uis.unesco.org/en/country/om (21/11/2021)

7 General Secretariat of the Education Council: https://www.educouncil.gov.om/en/page.php?scrollto=start\&id=41 $(21 / 11 / 2021)$. 
(NCSI, 2020, p. 421), which is marginal compared to 33,088 enrolments at colleges of technology (NCSI, 2020, p. 415) and to the student population of private training institutions ${ }^{8}$.

Throughout the years, the public TVET system has experienced various reforms. In the mid-1990s, the government decided to adopt the British system of National Vocational Qualifications (NVQ), although this was deemed unsuccessful and dropped soon after (Al-Raisi, 2000; Klaffke, 2010; Wilkins, 2002). In 2005, the government signed a cooperation agreement with the German GTZ (now GIZ) ${ }^{9}$ aiming to reform the Omani TVET system in line with German TVET traditions of strong private sector involvement. Moulded on the example of the German $\mathrm{BIBB}^{10}$, the Occupational Standards and Training Center (OSTC, now OSC) was founded in 2011 with the purpose of introducing a system of Advanced Occupational Standards as the basis for standardised TVET curricula (Jax, 2012; Klaffke, 2010). While cooperation with the GIZ was terminated, the OCS continues to develop what are now called National Occupational Standards in collaboration with respective industries. Sector Skills Councils were introduced to strengthen involvement of the private sector in curriculum development.

Trade unions have been permitted since 2006, having been introduced through a topdown approach and in the context of reinforcing labour policies to boost Omanisation in the private sector (Louër, 2015). The Omani trade union federation (General Federation of Oman Workers) confirms an interest in work-based learning (Bridgford, 2017), but has so far played a limited role in national skill formation policies.

Entrepreneurship education was introduced more than a decade ago (Masri et al., 2010). Following the social unrest in 2011, the government made it mandatory in higher education, hoping to encourage Omani start-ups (Al Shabibi, 2020, p. 45). However, scholars disagree on the effects of entrepreneurship education (Belwal et al., 2015; Ibrahim et al., 2017).

\section{Findings: Weak Incentive Structures and Weak TVET Systems are Mutually Reinforcing}

Our research identified challenges in both the TVET system and the socioeconomic structure. Quality issues and conservative teaching and learning patterns in the general education system affect TVET as much as higher education. Weak cognitive skills, above all in English proficiency and STEM subjects, as well as weak analytical and creative skills, are perceived to result from little instructional time in schools, low participation rates in early childhood care and education, as well as traditions of teacher-centred instruction and rote learning ( $\mathrm{Al}$

\footnotetext{
8 The total number of enrolments at private training institutions is difficult to assess. According to Al-Mujaini (2018, p. 18) 25,702 trainees completed their training at private training institutions in 2014

9 Deutsche Gesellschaft für Internationale Zusammenarbeit (formerly: Deutsche Gesellschaft für Technische Zusammenarbeit): www.giz.de (21/11/2021)

${ }_{10}$ The German Federal Institute for Vocational Education and Training: www.bibb.de (21/11/2021)
} 
Najar, 2016; Al-Shababi \& Silvennoinen, 2018; Gonzalez et al., 2008; World Bank \& Oman Ministry of Education, 2012).

Despite several reform efforts, TVET is still considered inferior to general secondary and higher education. Based on its marginal societal position, many shortcomings persist in the TVET system. Cooperation between the private sector and TVET is weak at many levels. Companies are reluctant to get involved in TVET both at the policy level and in terms of initial training. With the exception of the oil and gas sector, business associations are weak and incipient, and TVET involvement is not among their priorities. Government efforts to set up cooperation structures between industry and TVET have had limited success and are mostly perceived as top-down governance without benefit for companies, especially in the manufacturing sector. Consequently, although work-based training forms part of the curricula in vocational and technological colleges, it is perceived to be weak. Apprenticeship schemes are marginal. This also applies to TVET trainer education, which is primarily theory-focused without meaningful work-based components. At the tertiary level, technical education is also perceived to emphasise theory over practice.

TVET policymaking appears to have followed international TVET models somewhat inconsistently, switching between Anglo-Saxon and German traditions. Currently, government policies and practices deploy a mixed approach. They generally follow the UK model of promoting a market-led system of private TVET provision, which is publicly accredited and supervised, whilst also experimenting with German-type dual models. However, since demand by the private sector for trained Omani youth is low, the state strongly intervenes through work placement agencies. Since government supervision capacities are limited, complaints about poor performance of private TVET providers are common. Placement practices related to Omanisation imperatives are mostly experienced by employers as top-down government imposition, while structured cooperation with employers is weak.

While there are obviously dysfunctionalities at the level of TVET provision and governance, the root causes appear to stem from shortcomings at the structural level. As can be said of many Arabic rentier economies, manual work does not enjoy the same status as other forms of employment. Consequently, most young people do not view TVET as a desirable option for career development. This leads, among other things, to low work ethic and weak commitment among Omani job-seekers in the private sector (Ali et al., 2017; Al-Kindi, 2007; Al Najar, 2016; Matriano \& Suguku, 2015; Samman, 2010).

The Omanisation system, established to change this situation, has been subject to debate. Some consider it to have had an adverse effect on productivity as a result of companies tending to employ Omanis in low-skilled positions or including them on their payrolls without expecting any services in return. Other critics claim that the strategy detracts political attention from necessary structural economic reforms (see Ali et al., 2017 for a literature review in the regional context). Ali et al. (2017) describe the employment dynamics that result from 
what has been called a social contract between Omani nationals and the government. Political consent is granted for the prospect of obtaining relatively well-paid and secure employment with short working hours and favourable retirement regulations in the public sector. This leads to little motivation among Omani youth to look for employment in the private sector. On the other hand, Ennis (2020) describes that young, unemployed and often well-educated Omanis increasingly experience life at the margins of the national labour market, with private sector companies clearly preferring expatriates. In this contested labour market, migrant workers, themselves subject to the highest levels of precariousness, view Omani applicants as a potential threat. Their coping strategies include the marginalisation or even exclusion of Omani colleagues from learning processes and knowledge transfer within workplaces.

Over the decades, employment policies have created a dual labour market of apparently privileged nationals hoping for jobs in the public sector and a little-protected, low-paid foreign workforce covering the skills requirements across all levels of the private sector. Against this background, the driving forces for the emergence of a dynamic skill formation culture are weak.

\section{Discussion: The Particularities of a Rentier Framed Political Economy of Skill Formation}

As we have seen, TVET provision in Oman is widely school or college-based, and company involvement in initial training is marginal. Following the typologies of skill formation systems outlined above, at first sight, Oman has similarities with statist systems based on strong public commitment and low involvement of firms. Its regulatory and governance patterns appear to be widely bureaucracy-based with social activities and training outcomes focused on knowledge transmission. However, the high number of private TVET providers, which, to a certain extent, tend to escape government regulation, shows the influence and strengths of market forces, as do oscillating TVET policy trajectories. This moves the Omani skills system closer towards a hybrid model.

It becomes obvious that it is not so much the relation between public and employer commitment to skills formation in itself, but rather the particular framing of a rentier state that shapes the political economy of skill formation in a way that results in a weak incentive structure for national skill development.

In the following, we will discuss the main particularities of the Omani rentier state in terms of skill formation. Recent research on entrepreneurship policymaking illustrates some basic dynamics. Al-Shabibi (2020) describes how rentier states do not have a history of putting human resources centre stage of their economic strategies. In Oman, the private sector has grown accustomed to drawing from an apparently endless supply of workers from the neighbouring South Asian subcontinent. Hence, the cost of industrial skill formation is borne elsewhere. Employment distribution in the public sector occurs along the lines of well- 
orchestrated power balances with educational credentials functioning as door openers. Yet, as Brandenburg (2013) describes, the segmented system of elite public vs mass private forprofit higher education secures a selective qualification system for public sector employment. The private sector is neither willing nor able to absorb the remaining mass of graduates. Government policies, although discursively committed to employment creation for Omani citizens, are caught between opposing pressures. The competitive logic of the neoliberal global economy pushes for liberalisation of the private sector and deregulation of the labour market to attract investments. In contrast, internal stability demands employment creation for the growing educated youth bulge (Ennis, 2020).

The shock of social unrest in 2011 has led to ad hoc policymaking. Ennis (2015) describes how, in the aftermath of 2011, policy efforts to support entrepreneurship as a means of employment creation have been inconsistent and evasive of structural change. Abiding by the imperative of minimal political cost and the need to appear to address social demands, these policies have ended up generating "reframed rentier practices" (Ennis, 2015, p. 129) since new entrepreneurship initiatives are part of familiar, albeit enlarged, rentier distribution networks. In his analysis of entrepreneurship education in Oman's higher education sector, Al-Shabibi (2020) concludes that, due to the lack of socio-economic structural change, while entrepreneurship education has led to more knowledge about entrepreneurialism among students, this has not, in practice, translated into notable changes in the labour market.

Based on our findings, we argue that similar patterns of policymaking can be identified in skill formation for industrial development. Efforts to improve the quality and reputation of TVET have failed to include any structural change at the level of production and employment. On the contrary, the private sector remains stuck in low skill-low productivity patterns based on workforce import. Two interconnected cycles of social processes shape skill formation in Oman. First, the availability of cheap and underprivileged expatriate labour and the traditional preference of Omani nationals for public sector jobs lead to a poor incentive structure for employing Omani nationals in the private sector. Second, reluctant employer attitudes towards national skill formation deepen quality issues in the TVET system, especially with regard to work-based training. This reinforces negative perceptions of the local workforce, which in turn contribute to biased employment patterns. Both social processes mutually reinforce each other, eventually preventing the emergence of strong national skill formation dynamics.

At the political level, inconsistent policymaking following imported TVET models that turn out to be inappropriate for the Omani context points to palliative rather than substantial reform approaches. As in many other countries, TVET is promoted as a key solution to youth unemployment. Politically, this allows, on the one hand, for the unemployment problem to be individualised and privatised. On the other hand, it allows for government policies to appear socially committed while remaining politically harmless. 
At the level of cultural and socio-political practices, two dynamics stand out that shape skill formation practices in Oman: first, the rentier mentality and second, the impact of a strongly hierarchical social order. Beblawi (1987) understands the rentier mentality as a dissociation of the work-reward causation, reward being associated with chance or situation rather than with work and risk-bearing. In Oman, this mentality is manifest in a pervasive disdain towards manual work. The success of Omanisation in the banking sector is illustrative in this respect. Although this success shows the translation of political will onto labour market developments, other factors such as competitive remuneration packages and career development opportunities have moved the banking sector closer to the public sector in terms of career attractiveness (Al-Lamki, 2005). This, complemented by the perception of banking jobs being "white collar" as opposed to manual work, emphasises that the barriers for Omanisation in the industrial sector have as much to do with cultural attitudes as they do with working conditions.

As for the impact of social hierarchies, Al-Shabibi (2020) notes the political price associated with entrepreneurial attitudes such as active risk-taking, innovation and creativity, since such mindsets can potentially undermine public consent with the current system of absolutist monarchic rule.

Some human resources literature (e.g. Al-Hamadi et al., 2007) describe how employeeemployer relations are shaped by hierarchical values and behavioural patterns moulded on family and tribal relations. For instance, boundary setting within the workplace shows collectivist thinking towards what is considered the in-group (family and tribe) and individualist thinking towards the out-group (non-kin and guest workers).

While there is clearly a need for more research, the impact of such cultural traditions on educational and skills imaginaries is evident. The persistent centrality of theoretical knowledge in all forms of education, including TVET, resonates with Wolf's (2017) distinction between different manifestations of social activities in TVET. In Oman's bureaucratically regulated TVET system, the critical social activity manifests itself as knowledge transmission rather than work execution or specific work-related behaviour. The oft-mentioned reluctance of teachers to adopt more learner-centred, practice-oriented and creativity-inducing teaching methods (Al-Najar, 2016; Al-Shababi \& Silvennoinen, 2018; Issan \& Gomaa, 2010; World Bank \& Oman Ministry of Education, 2012) might have to do with the strong value of hierarchies in Omani society and with the political sensitivity of questioning them.

To sum up, the rentier mentality in a strongly hierarchical social order generates social understandings and practices of work that see respect for tradition and hierarchies much more effective in terms of access to rentier distribution networks than skilled work in the productive sector. 


\section{Conclusions}

In this paper, we have argued that persistent quality challenges in the Omani TVET system cannot be explained by analysing the level of TVET provision, just as skill deficits cannot explain low employment rates of Omanis in the private sector. Rather, TVET provision must be considered part of the more comprehensive skill formation regime in its dialectic relation with economic and employment structures as well as the social-cultural context. Indeed, in a vicious cycle, the lack of an incentive structure for national industrial skill formation, typical for a rentier society, reinforces shortcomings in TVET quality and provision, which again feed into the image of an unproductive Omani workforce.

Hence, while immediate reform needs of the national TVET system point to necessary improvements in work-based training opportunities, stronger linkages between companies and TVET institutions and better cooperation among the involved government entities, it is obvious that this will not suffice to create a viable TVET system as long as the structural level is not tackled.

We have attempted to contribute to the scarce political economy of skills literature beyond Western contexts. While not directly transferable to other countries, our analysis of skill formation in Oman might prove valuable for the study of similar rentier states, in particular those in the Arab Gulf region. Using two different classifications of skill formation patterns complementarily has allowed us to show how socio-economic and cultural contexts combine to generate particular skill development dynamics. The institution-focused classification by Busemeyer and Trampusch (2012a) sheds light on the way in which the dominance of the rent-securing oil and gas sector impedes the emergence of a strong incentive structure of skill formation. In addition, the model by Wolf (2017) helps to gain an understanding of how rentier practices have shaped a particular imaginary of work unconducive to manual labour and skills acquisition.

Our paper thus attempts to contribute to the theoretical understanding of the particular political economy of skill formation in a rentier state such as Oman. While sharing strong state interventionism with the "developmental model of skill formation" (Ashton et al., 2002, p. 11) of the East-Asian development states, Oman's rentier model is essentially different. In the former, a strong private sector generates skills needs, leading to concerted national policy efforts towards upskilling. Socio-cultural understandings of work are linked to collective efforts of national wealth-building. The respective social contract underpinning socioeconomic relations grants participation in economic profit in exchange for highly productive work. In contrast, Oman's social contract is based on access to rent-distribution networks in exchange for political consent. In such a setting, and regardless of government discourses on skills development, a highly-skilled national workforce is less imperative for political stability than one that is respectful of hierarchies. 
In Oman, as in other countries, immediate structural change seems unrealistic given global economic interconnectedness at multiple levels. However, with a view to improving employment opportunities, it seems imperative that we move beyond the global fashion of conceiving TVET as a remedy for deeper structural issues. Instead, more research is needed into how skill formation relates to specific socio-economic structures, how employment dynamics relate to educational credentials and how cultural traditions shape educational and work practices.

\section{References}

Al-Hamadi, A. B., Budhwar, P. S., \& Shipton, H. (2007). Management of human resources in Oman. The International Journal of Human Resource Management, 18(1), 100-113. https://doi. org/10.1080/09585190601068383

Ali, Y. Y., Al-Nusair, M. M., Alani, F. S., Khan, F. R., \& Al-Badi, L. H. (2017). Employment in the private sector in Oman: Sector-based approach for localization. Humanities \& Social Sciences Reviews, 5(1), 01-20. https://doi.org/10.18510/hssr.2017.511

Al-Kindi, T. (2007). Economic policy and reform of skill formation in relation to VET: The case of Sultanate of Oman. University of Cardiff.

Allais, S. (2020a). Vocational education and inequalities in transitions from education to work in three African countries. In D. Francis, I. Valodia \& G. Webster (Eds.), Inequality studies from the global south (pp. 143-160). Routledge. https://doi.org/10.4324/9780429282447

Allais, S. (2020b). Skills for industrialisation in sub-Saharan African countries: Why is systemic reform of technical and vocational systems so persistently unsuccessful? Journal of Vocational Education \& Training, 1-19. https://doi.org/10.1080/13636820.2020.1782455

Al-Lamki, S. M. (2005). The role of the private sector in Omanization: The case of the banking industry in the Sultanate of Oman. International Journal of Management, 22(2), 176-188.

Al-Lamki, S. M. (2000). Omanization: A three tier strategic framework for human resource management and training in the Sultanate of Oman. Journal of Comparative International Development, 3(1).

Al-Mujaini, D. A. O. (2018). An overview of the TVET system in the Sultanate of Oman. UNESCO Beirut Office.

Al Najar, N. (2016). View of education development in Oman. Academic Research International, 7(2), $133-145$.

Al-Raisi, F. H. J. (2000). Technical and vocational education in the Sultanate of Oman. Conference Paper. https://www.voced.edu.au/content/ngv\%3A852

Al-Rawahi, M. (2011). An assessment of the current vocational education and training in the Government Vocational Training Centers in the Sultanate of Oman. University of Salford Manchester.

Al-Shababi, A., \& Silvennoinen, H. (2018). Challenges in education system affecting teacher professional development in Oman. Athens Journal of Education, 5(3), 261-282.

Al Shabibi, I. (2020). Planning for entrepreneurialism in a rentier state economy: Entrepreneurship education for economic diversification in Oman. Cardiff University.

Ashton, D., Green, F., Sung J., \& James, D. (2002). The evolution of education and training strategies in Singapore, Taiwan and S. Korea: A development model of skill formation, Journal of Education and Work, 15(1), 5-30. https://doi.org/10.1080/13639080120106695 
Beblawi, H. (1987). The rentier state in the Arab World. Arab Studies Quarterly, 9(4), 383-398.

Belwal, R., Al-Balushi, H., \& Belwal, S. (2015). Students' perception of entrepreneurship and enterprise education in Oman. Education \& Training, 57(8-9), 924-947. https://doi.org/10.1108/ET-12-20140149

Bogner, A., Littig, B., \& Menz, W. (2009). Interviewing experts. Palgrave Macmillan. https://doi. org/10.1057/9780230244276

Brandenburg, T. (2013). The political economy of internationalization and privatization of higher education in the Sultanate of Oman. In S. Wippel (Ed.), Regionalizing Oman: Political, economic and social dynamics (pp. 289-303). Springer. https://doi.org/10.1007/978-94-007-6821-5

Bridgford, J. (2017). Trade union involvement in skills development: An international review. ILO.

Brown, P., Lauder, H., \& Ashton, D. (2011). The global auction: The broken promises of education, jobs, and incomes. Oxford University Press. https://doi.org/10.1093/acprof:oso/9780199731688.001.0001

Busemeyer, M. R., \& Trampusch, C. (2012a). The comparative political economy of collective skill formation. In M. R. Busemeyer \& C. Trampusch (Eds.), The political economy of collective skill formation (pp. 3-41). Oxford University Press. https://doi.org/10.1093/acprof:oso/9780199599431.001.0001

Busemeyer, M. R., \& Trampusch, C. (Eds.) (2012b). The political economy of collective skill formation. Oxford University Press. https://doi.org/10.1093/acprof:oso/9780199599431.001.0001

Bürgi, R., \& Gonon, P. (2021). Varieties within a collective skill formation system: How VET governance in Switzerland is shaped by associations. International Journal for Research in Vocational Education and Training, 8(1), 46-64. https://doi.org/10.13152/IJRVET.8.1.3

Deissinger, T., Aff, J., Fuller, A., \& Helms Jorgensen, C. (Eds.). (2013). Hybrid qualifications: Structures and problems in the context of European VET policy. Peter Lang.

Ennis, C. A. (2015). Between trend and necessity: Top-down entrepreneurship promotion in Oman and Qatar. The Muslim World, 105(1), 116-138. https://doi.org/10.1111/muwo.12083

Ennis, C. A. (2020). Citizenship without belonging? Contesting economic space in Oman. International Journal of Middle East Studies, 52(4), 759-764. https://doi.org/10.1017/S0020743820001063

Gonzalez, G., Karoly, L. A., Constant, L., Salem, H., \& Goldman, C. (Eds.). (2008). Facing human capital challenges of the 21st century: Education and labor market initiatives in Lebanon, Oman, Qatar, and the United Arab Emirates. RAND Corporation.

Graf, L. (2013). The hybridization of vocational training and higher education in Austria, Germany, and Switzerland. Verlag Barbara Budrich. https://doi.org/10.2307/j.ctvbljt2g

Graf, L. (2016). The rise of work-based academic education in Austria, Germany and Switzerland. Journal of Vocational Education \& Training, 68(1), 1-16. https://doi.org/10.1080/13636820.2015.1107749

Greinert, W.-D. (1995). Regelungsmuster der beruflichen Bildung. Tradition - Markt - Bürokratie. Berufsbildung in Wissenschaft und Praxis - BWP, 24(5), 31-35.

Greinert, W.-D. (2005). Mass vocational education and training in Europe. Classical models of the 19th century and training in England, France and Germany during the first half of the 20th century. Cedefop.

Greinert, W.-D. (2017). Berufsqualifizierung in Europa: Ein Vergleich von Entstehung und Entwicklung der drei klassischen Modelle. Schneider Verlag Hohengehren GmbH.

Hammersley, M. (2008). Troubles with triangulation. In M. M. Bergmann (Ed.), Advances in mixed methods research (pp. 22-36). Sage.

Ibrahim, O. A., Devesh, S., \& Ubaidullah, V. Z. (2017). Implication of attitude of graduate students in Oman towards entrepreneurship: An empirical study. Journal of Global Entrepreneurship Research, 7(8), 1-17. https://doi.org/10.1186/s40497-017-0066-2 
Issan, S., \& Gomaa, N. M. M. (2010). Post basic education reforms in Oman: A case study. Literacy Information and Computer Education Journal, 1(1), 19-27.

Jax, A. (2012). Entwicklung bedarfsgerechter Ausbildungsstandards zur Qualitätssicherung in der Berufsbildung am Beispiel des Sultanats Oman. Lernen \& Lehren, 1/2012, 32-39.

Klaffke, H. (2010). Entwicklung und Anwendung von 'Advanced Occupational Standards' im Sultanat Oman. Berufsbildung in Wissenschaft und Praxis - BWP. 3(2010). 45-48.

Louër, L. (2015). The Arab Spring effect on labor politics in Bahrain and Oman. Arab Humanities, 4. https://doi.org/10.4000/cy.2865

Masri, M., Jemni, M., Al-Ghassani, A. M., \& Badawi, A. A. (2010). Entrepreneurship education in the Arab States. UNESCO Paris.

Matriano, M. T., \& Suguku, D. (2015). Entrepreneurship growth in Oman: Position, prospects and growth of entrepreneurial education. International E-Journal of Advances in Education, 1(2), 127-131.

Mayring, P. (2010). Qualitative Inhaltsanalyse. Grundlagen und Techniken. Beltz.

Nasser, R. (2020). Educational reform in Oman: System and structural changes. In G. Porto (Ed.), Education systems around the world. https://doi.org/10.5772/intechopen.84913

National Centre for Statistics \& Information. (2020). Statistical year book 2020.

Ohnsorge, F., \& Yu, S. (2021). The long shadow of informality: Challenges and policies. World Bank.

Oman Vision 2040. (n.d.). Moving forward with confidence. Vision document.

Peterson, J. E. (1978). Oman in the twentieth century. Political foundations of an emerging state. Croom Helm Ltd.

Riyada (2018). Mapping the SME ecosystem in Oman. Muscat.

Samman, H. (2010). Meeting the employment challenge in the Gulf Countries Council GCC. The need for a holistic strategy. Dubai, UAE: Zawya Ltd.

Souto-Otero, M., \& Ure, O. B. (2012). The coherence of vocational education and training in Norway and Spain: National traditions and the reshaping of VET governance in hybrid VET systems. Compare: A Journal of Comparative and International Education, 42(1), 91-111. https://doi.org/10.1080/03057 925.2011.628836

Streeck, W. (2012). Skills and politics: General and specific. In M. R. Busemeyer \& C. Trampusch (Eds.), The political economy of collective skills formation (pp. 317-353). Oxford University Press. https://doi. org/10.1093/acprof:oso/9780199599431.003.0012

UNICEF \& ILO. (2016). Consultation on technical and vocational education and training in the Middle East and North Africa. Workshop Report Amman.

Valeri, M. (2013). Domesticating local elites, sheikhs, walis and state-building under Sultan Qaboos. In S. Wippel (Ed.), Regionalizing Oman: Political, economic and social dynamics (pp. 267-277). Springer. https://doi.org/10.1007/978-94-007-6821-5_16

Wilkins, S. (2002). The implementation of NVQs in the Sultanate of Oman. Education + Training, 44(3), 144-152. https://doi.org/10.1108/00400910210424364

Wolf, S. (2017, April 4). Berufsbildungssysteme international - Typologien und Analysewerkzeuge zum Verständnis internationaler Erwerbsqualifzierung: Vortrag bei Don Bosco Mondo zum Thema. TU Berlin. Don Bosco Mondo.

Wolf, S. (2018). Theoretische Rahmungen und historische Erfahrungen für einen Austausch mit Entwicklungsländern zur Weiterentwicklung der Erwerbsqualifizierung. In M. Gessler, M. Fuchs \& M. Pilz (Eds.), Konzepte und Wirkungen des Transfers Dualer Berufsausbildung (pp. 551-599). Springer. https://doi.org/10.1007/978-3-658-23185-9_15 
Wolf, S. (2021a). Theoretical frameworks and historical experiences of industrialisation for an exchange with developing countries for the further development of qualification for employment. In P. Eigenmann, P. Gonon \& M. Weil (Eds.), Opening and extending vocational education (pp. 43-74). Peter Lang. https://doi.org/10.3726/b17572/12

Wolf, S. (2021b). Tools and means to facilitate understanding of TVET models in developing countries: A conceptual approach based on international comparative TVET research. In M. Makgato \& G. Afeti (Eds.), New models for technical and vocational education and training (pp. 214-243). IGI Global.

World Bank \& Oman Ministry of Education. (2012). Education in Oman. Drive for quality.

Worrall, J. (2012). Oman: The 'forgotten' corner of the Arab Spring. Middle East Policy, 19(3), 98-115. https://doi.org/10.1111/j.1475-4967.2012.00550.x

\section{Biographical Notes}

Dr Margarita Langthaler holds an MA in Roman and Slavic philology and a doctoral degree in political science from the University of Vienna. She is a Senior Researcher with the Austrian Foundation for Development Research (ÖFSE) and a lecturer at the University of Vienna, Department of Development Studies. Her work focuses on education policy in developing countries, technical and vocational education and training in developmental contexts, and education and development cooperation.

Dr phil. habil. Stefan Wolf is Associate Professor at the Technische Universität Berlin, Department of Vocational Education and School Pedagogy. Until 2020, he has also headed the department of Vocational Special Need Education and Vocational Rehabilitation at the Technische Universität Dortmund as deputy professor. His research interests include vocational didactics and pedagogy for teachers and applied historical systematic TVET research. In the field of international comparative vocational education, he specifically focuses on cultural studies, critical science, and post-colonial approaches to science. He has extensive international experience as an academic and consultant through various development agencies.

Dr Tobias Schnitzler is currently working as a Project Coordinator for the World University Service (WUS) Austria. In 2020, he received his Doctoral Degree in Social and Economic Sciences at the Institute for Ecological Economics from the Vienna University of Economics and Business (WU). The focus of his dissertation lies on how collaborative and transformative learning (TL) could be linked to education for sustainable development (ESD). Furthermore, he holds MAs in International Development from the University of Vienna and Environmental Ethics from the University of Augsburg. 